O. VYŠATA, ${ }^{1,2}$ M. VALIŠ, ${ }^{2}$ A. PROCHÁZKA, ${ }^{1}$ R. RUSINA, $, 3,4$ and L. PAZDERA ${ }^{5}$

\title{
LINEAR AND NONLINEAR EEG SYNCHRONIZATION IN ALZHEIMER'S DISEASE
}

\author{
Received October 30, 2013
}

\begin{abstract}
As is known, Alzheimer's disease (AD) is associated with cognitive deficits due to significant neuronal loss. Reduced connectivity might be manifested as changes in the synchronization of electrical activity of collaborating parts of the brain. We used wavelet coherence to estimate linear/nonlinear synchronization between EEG samples recorded from different leads. Mutual information was applied to the complex wavelet coefficients in wavelet scales to estimate nonlinear synchronization. Synchronization rates for a group of 110 patients with moderate AD (MMSE score 10 to 19) and a group of 110 healthy control subjects were compared. The most significant decrease in mutual information in AD patients was observed on the third scale in the fronto-temporal area and for wavelet coherence within the same areas as for mutual information; these areas are preferentially affected by atrophy in AD. The new method used utilizes mutual information in wavelet scales and demonstrates larger discriminatory values in $\mathrm{AD}$ compared to wavelet coherence.
\end{abstract}

Keywords: Alzheimer's disease (AD), electroencephalography, EEG synchronization, mutual information, wavelet coherence.

\section{INTRODUCTION}

The level of synchronization of neural activity is an important parameter that demonstrates the intensity of coordination of activities of different parts of the brain [1].

The theory of complex systems describes several types of synchronization. Identical oscillators must be sufficiently interlinked for complete synchronization to occur. In the electroencephalogram, this type of synchronization resembles the situation observed in epileptic seizures. Generalized synchronization [2] reflects specific functional relationships between the states of two systems. Phase synchronization, first described using coupled chaotic oscillators [3], might present noncorrelated amplitudes of the respective oscillations.

Alzheimer's disease (AD) is associated with the

\footnotetext{
${ }^{1}$ Department of Computing and Control Engineering, Institute of Chemical Technology, Prague, Czech Republic.

${ }^{2}$ Department of Neurology, Faculty of Medicine in Hradec Králové, Charles University, Hradec Králové, Czech Republic.

${ }^{4}$ Department of Neurology, Thomayer Hospital and Institute for Postgraduate Education in Medicine, Prague, Czech Republic.

${ }^{5}$ Department of Neurology and Centre of Clinical Neuroscience, First Faculty of Medicine, Charles University in Prague, and General University Hospital in Prague, Czech Republic.

${ }^{6}$ Neurocentre Caregroup Ltd., Rychnov nad Kneznou, Czech Republic.

Correspondence should be addressed to $O$. Vyšata

(e-mailvysatao@gmail.com)
}

loss of synchronization between EEGs recorded from different sites (channels), which, in addition to slowing down of background activity and decrease in its complexity, provides a promising target for analyses [4]. Currently, there are efforts to identify the most sensitive method for estimation of the synchronization loss in the diagnosis of early stages of AD. Different techniques have been used to estimate the extent of synchronization between two or more EEG processes. Linear relationships between signals might be estimated using cross-correlation functions. Moreover, the frequency range correlation might be estimated using the spectral coherence function, and correlations in wavelet scales might be estimated using wavelet coherence. Unlike other techniques, wavelet coherence exhibits an advantage related to the greater time and frequency resolution and is considered an effective tool for identification of the changes in brain activity during aging and in the early AD stages [1]. The usefulness of wavelet coherence in EEG analysis was first proposed by Lachaux in 2002 [5]. In 2006, Klein showed that wavelet coherence is a more sensitive indicator of the EEG changes during sensory stimulation compared to traditional coherence [6]. In 2006, Sakkalis applied this method to study the disconnection syndrome in schizophrenia [7]. The first attempt to study changes in AD using EEG wavelet coherence was described by Sankari in 2012. Mutual 
information derived from the theory of information was used to estimate the degree of nonlinear correlation between EEGs of different channels [8,9]. This technique has been repeatedly used to estimate nonlinear EEG associations in patients with AD. However, this technique has never been used to assess EEGs in multiple frequency bands. A certain reduction in mutual information has been previously reported in the frontal and right anterior temporal areas and in the inter-hemispheric pathways in the respective cases [10]. Transfer entropy [11], Granger causality [12], and nonlinear interdependence [13] are other nonlinear measures of synchronization.

Because different brain subsystems produce oscillations of different frequencies, it is expedient to study interrelations between such oscillations for different frequency ranges. The spectral correlation function and wavelet coherence are linear measures of the similarity that provide a multiband perspective. Because EEG signals are, in principle, nonstationary, wavelet transformation-based coherence rather than Fourier transformation-based coherence is suitable for modeling the relationships between EEG channels. Thus, wavelet coherence was used to evaluate the degree of linear relationship in our study. Transfer entropy and Granger causality are asymmetric measures that determine the direction of information propagation and are difficult to be compared with wavelet coherence results.

The nonlinear interdependence method [13] relies on the state of space reconstruction and is more suitable for the description of chaotic oscillators. As the presence of a deterministic chaos in EEG is a controversial topic, we used mutual information in wavelet scales to estimate nonlinear relationships. Among the available wavelet transformation techniques, we used complex wavelet transformation.

It is expected that brain dynamics are strongly affected by neuroanatomical connectivity. Alzheimer's disease is a progressive neurodegenerative pathology clinically characterized by significantly impaired memory and other cognitive dysfunctions. Previous studies have shown that this disorder is associated not only with regional brain abnormalities but also with changes in the neuronal connectivity between anatomically distinct brain regions. Cortical areas of patients with AD show suboptimal topological organization [14]. A global connectivity deficit was found in $\mathrm{AD}$ [15].

Memory and cognitive impairments are associated with changes in the coordination of activities of functional neural networks. Using neurophysiological and imaging techniques, as well as computational approaches based on graph theory, Stem et al. [16] showed that AD patients demonstrate impaired neuronal integrity in the major structural and functional systems of the brain such as the associative cortex, hippocampus, prefrontal cortex, and cerebellum. In this case, it is expedient to observe changes in the functional organization of the brain in patients with $\mathrm{AD}$ under resting conditions (as the background pattern) [17].

The aim of our study was to compare the selected linear and nonlinear association estimates of EEG samples between patients suffering from $A D$ and control subjects.

\section{METHODS}

Subjects. In our prospective study, the EEG data were obtained during examinations of $110 \mathrm{AD}$ patients with moderate dementia (MMSE score 10 to 19). All these subjects underwent brain CT, as well as neurological and neuropsychological examinations. The control group consisted of 120 age-matched healthy subjects with no memory or other cognitive impairments. All of these patients had normal neuropsychological examinations and did not undergo brain CT. The mean MMSE of the AD group was $15.8 \pm 1.7(\mathrm{M} \pm$ s.d. $)$. The mean age of the AD patients and control subjects was $71.5 \pm 6.8$ and $69.1 \pm 5.7$ years, respectively. There were 52 men and 68 women in the AD group and 54 men and 66 women in the control group.

EEG Recording and Preprocessing. All recordings were performed under similar standard conditions. The subjects were placed in a comfortable position, on a bed, with their eyes closed. The electrodes were positioned according to the 10-20 electrode placement system; the recording was conducted using a 21-channel digital EEG setup (TruScan 32, Alien Technik Ltd., Czech Republic) with a 22-bit AD conversion and a sampling frequency of $128 \mathrm{sec}^{-1}$. The filter settings were 0.5 and $60 \mathrm{~Hz}$. The linked ear contacts were used as references.

Stored digitized data were zero-phase digitally filtered using a bandpass FIR filter (100 coefficients, Hamming window) of $0.5-60 \mathrm{~Hz}$ and a bandstop filter of $49-51 \mathrm{~Hz}$. The analysis began after manual removal of the artefacts. Five to six 60 - to 80 -sec-long segments were manually selected from each 20-minlong record. All of the curves in these segments were 
normalized using the median.

Mutual Information and Wavelet Coherence

Estimation. Both measures of similarity were estimated for all EEG channel pairs (171) in five wavelet scales. The mutual information was calculated for absolute values of the wavelet transformation coefficients in each scale. Continual wavelet coherence values were averaged in each segment for each electrode pair, and calculations were performed using MATLAB.

Statistics. We estimated the presence of significant differences between the values for the $A D$ and control groups using a two-sample $t$-test. The data met the criteria for the Shapiro-Wilk test for the normal distribution. In addition, records from 171 electrode pairs were compared in five wavelet scales in both groups, and $P$ values were adjusted using the Bonferroni approach for multiple comparisons $(n=855)$.

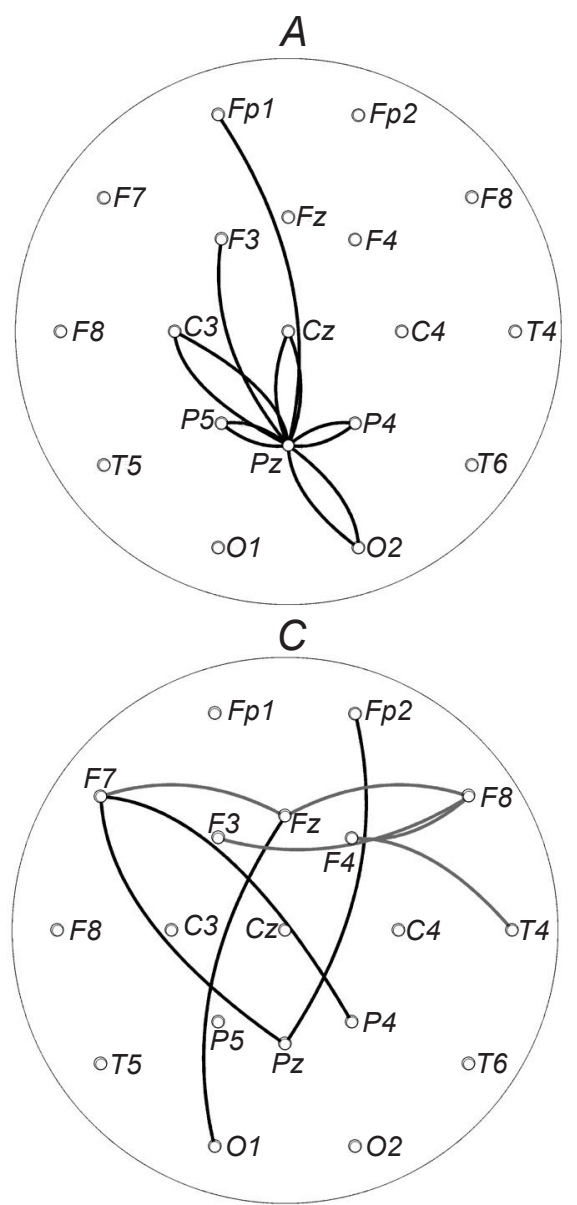

\section{RESULTS}

The number of electrode pairs with a statistically significant increase in mutual information decreased from the first to the fifth wavelet scale, i.e., decreased with decreasing frequency (Table 1). An inverse trend was evident for a reduction in mutual information.

There was no statistically significant reduction for any pair of electrodes on the first or second scale. In $\mathrm{AD}$ patients, the centroparietal area showed the most significant increase in mutual information in all wavelet scales, which was mainly believed to be related to short connections between neighboring sites. In contrast, the frontolateral and temporal areas showed maximum reductions of this value in the third to fifth wavelet scales (Fig. 1). Furthermore, the wavelet coherence decreased in the same area, predominantly for the right hemisphere, in all of the

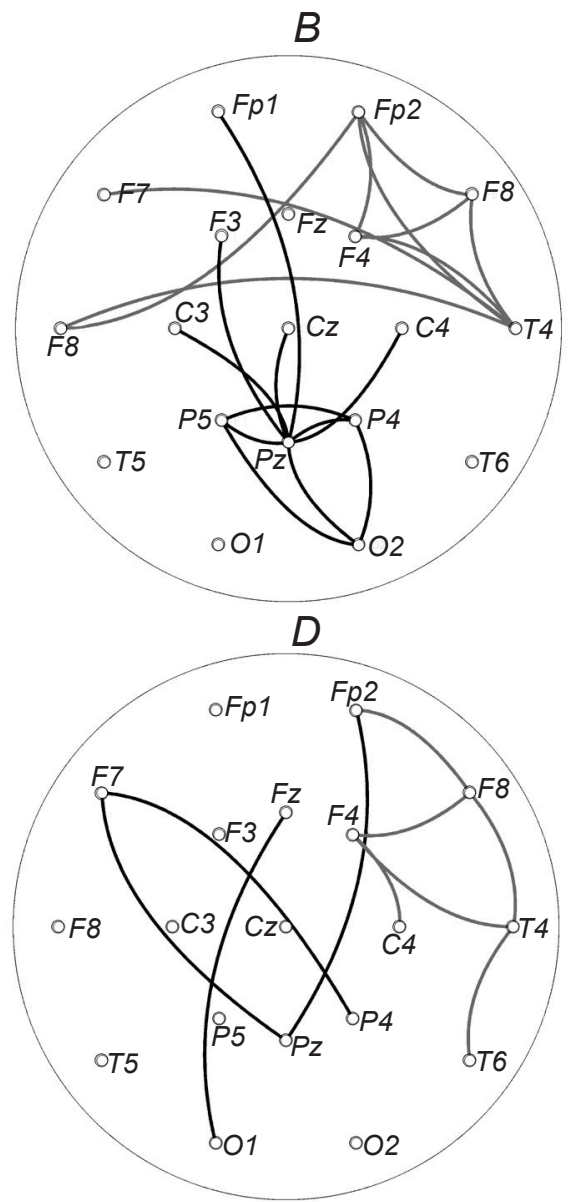

F i g. 1. Location of the most statistically significant electrode pairs for wavelet coherence and mutual information in the second and third scales. Reduction is depicted in gray, and increase is shown in black. A and B) Mutual information scales; C and D) wavelet coherence scales.

P и с. 1. Локалізація найбільш статистично вірогідних локусів відведення ЕЕГ при визначенні індексів вейвлет-когерентності та взаємної інформації за другою та третьою шкалами. 
TABLE 1: Number of channel pairs with significantly reduced and increased wavelet coherence and mutual information scales in the wavelet scale at $\boldsymbol{P}<0.01$ (after Bonferroni correction; $1.2 \cdot 10^{-5}$ )

Т а б л и ц я 1. Кількість пар локусів відведення ЕЕГ з істотними зменшеннями або збільшеннями індексів вейвлеткогерентності та взасмної інформації за вейвлет-шкалою з $P<0.01$

\begin{tabular}{|c|c|c|c|c|}
\hline Wavelet scale & \multicolumn{2}{|c|}{ Wavelet coherence } & \multicolumn{2}{|c|}{ Mutual information } \\
\hline 1 & 72 & 39 & 0 & 171 \\
\hline 2 & 79 & 41 & 0 & 166 \\
\hline 3 & 47 & 67 & 16 & 100 \\
\hline 5 & 72 & 37 & 125 & 17 \\
\hline
\end{tabular}

TABLE 2: Four pairs of channels with the most significant differences in wavelet coherence and mutual information in the wavelet scale values for patients with Alzheimer's disease (AD) and control-group (CG) subjects. All differences were significant at $P<0.01$ (after Bonferroni correction, $\mathbf{1 . 2 \cdot 1 0 ^ { - 5 }}$ )

Т а б л и ц я 2. Чотири пари локусів, для яких спостерігалися найістотніші відмінності значень вейвлет-когерентності та взасмної інформації у паціснтів із хворобою Альцгеймера та осіб групи контролю

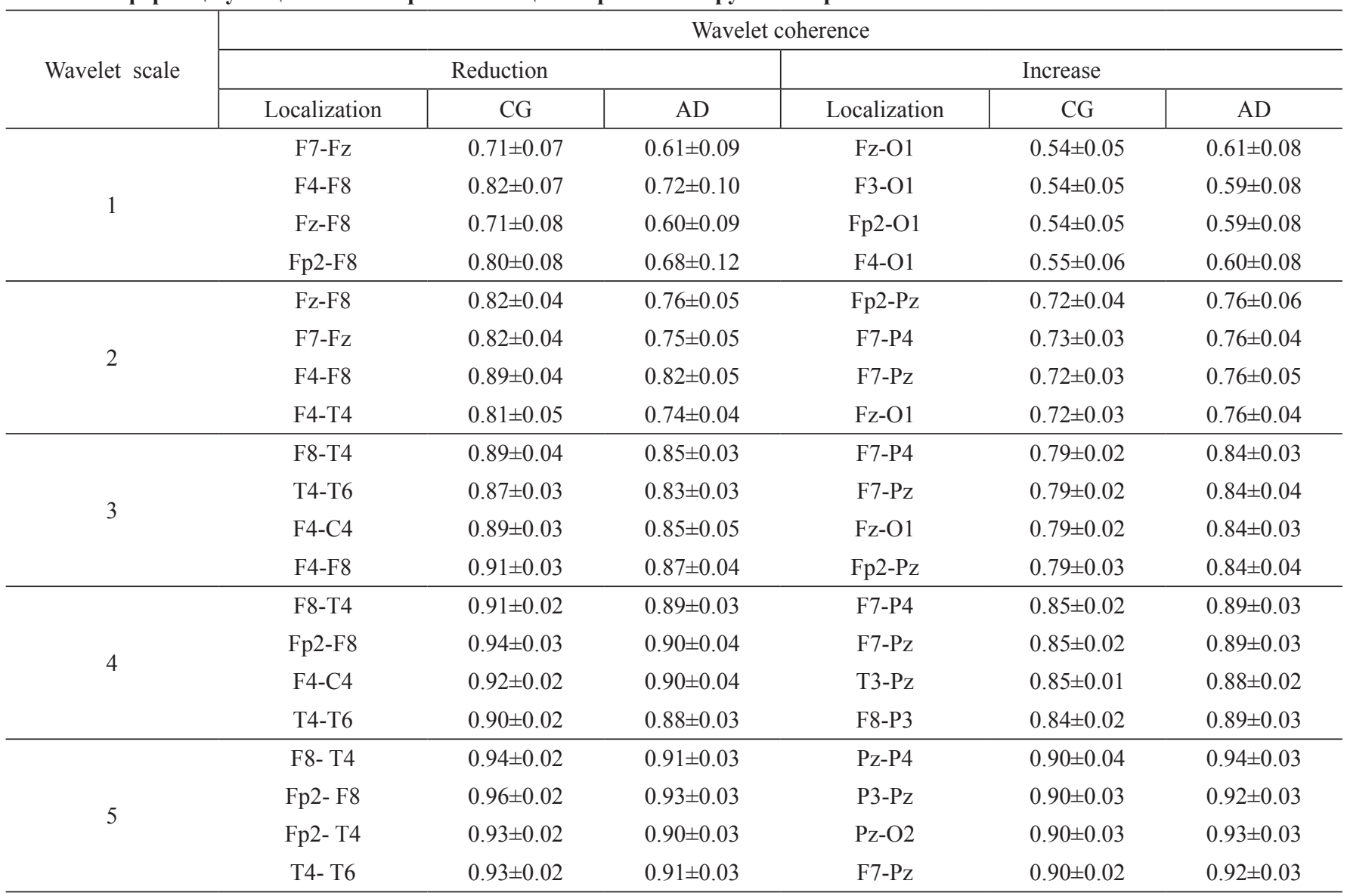

scales, but with the most significant values in the second and first wavelet scales (Table 2, Fig. 1).

Distribution of the significant values for the increase in wavelet coherence differed from the mutual information and was the most significant for long frontoparietal and frontooccipital pathways. 


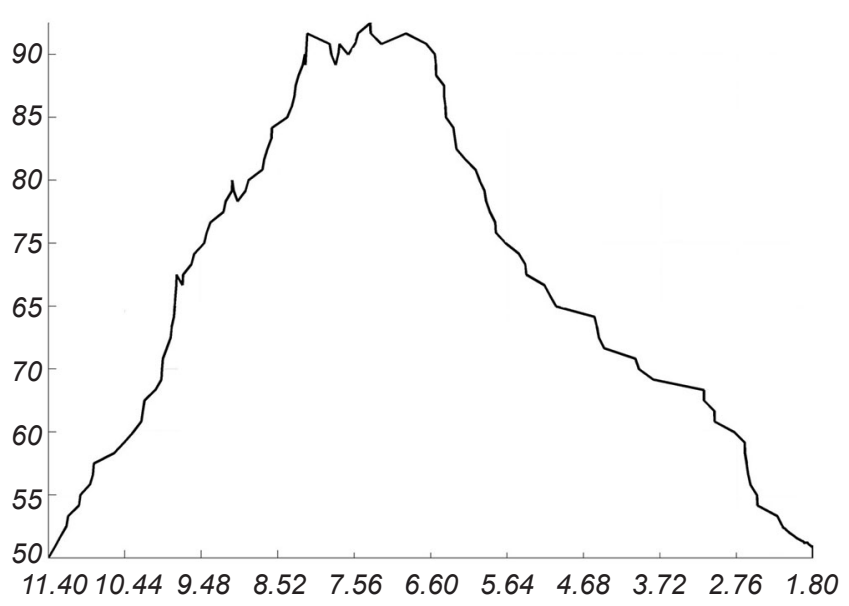

F i g. 2. Example of accuracy of calculation for an increase in mutual information in Alzheimer's disease for the P3-Pz electrode pair.

P и с. 2. Приклад розрахунку точності щодо збільшення значень взаємної інформації при хворобі Альцгеймера для пари відведень Р3-Pz.

A good discriminatory ability of mutual information was apparent on the representative histograms plotted from the ROC curves and accuracy values; examples are presented in Fig. 2. The accuracy of the ROC curve separation was $92.5 \%$ (Fig. 2).

\section{DISCUSSION}

Linear and nonlinear estimates of EEG channel synchronization suggest that two processes are involved, where one process results in reduced high-frequency values in patients with $\mathrm{AD}$ in the frontolateral and parietal areas. Another process results in increases in the frontoparietal and frontooccipital values in the lowest-frequency wavelet scales. The increase exhibits an even higher discriminatory value when compared with the other two groups than the reduction. A previous comparative study [1] showed reductions in the wavelet coherence for the temporolateral, temporoparietal and temporooccipital areas in the delta range and for the majority of the electrode pairs in the alpha, theta, and beta bands. In contrast to our results, Sankari et al. [1] found no statistically significant predominant increases in the wavelet coherence in the frontal and frontopolar electrodes, most likely due to a considerably smaller patient sampling.

The lack of a significant reduction in the first and second wavelet scales when estimating nonlinear relationships between the channels using mutual information indicated the importance of using this synchronization measure in multiple frequency bands. When comparing the wavelet coherence and mutual information in wavelet scales, the most significant increase in mutual information was observed at the lowest frequencies, and the most significant reduction was observed at the highest frequencies. We did not observe this frequency-dependent pattern for wavelet coherence.

The differences between both methods suggested that the interrelationship between the EEGs recorded from different channels was nonlinear. This newly proposed method utilizes mutual information on absolute values of the complex wavelet coefficient in the wavelet scales, and it displayed a greater discriminatory value compared to wavelet coherence (Table 2).

Most strikingly, AD patients, compared to the control group, demonstrated increased synchronization with the maximum in the third wavelet scale in the centroparietal area for both linear and nonlinear synchronization rates. Similar changes were observed when the subjects were presented with fearinducing stimuli. We assumed that our patients with $\mathrm{AD}$ developed some stress responses and increase in the anxiety level caused by an unknown environment of the EEG laboratory. This was potentiated by the presence of medical instruments and machinery in the room. However, the decrease in the values for both methods in the frontolateral area was an expected consequence of atrophy-dependent disorders of neuroanatomical connectivity in the frontal and temporal lobes in patients suffering from $\operatorname{AD}[4,18]$.

Both techniques are based on wavelet transformation, which is more suitable for multiresolution analysis of nonlinear and nonstationary signals such as EEGs, compared to Fourier transformation that requires linearity. Mutual information that estimates linear as well as nonlinear relationships has a higher discriminatory potency for the comparison of the two groups, which supports the presence of nonlinear relationships between EEG channels.

Continuous wavelet coherence also enables monitoring of temporal changes between channels in different wavelet scales. However, this advantageous feature was lost in our study because the evaluated sections were averaged. The differences in the relationship timeline may provide additional information and enhance the usefulness of this method. Because the calculated value for mutual information is dependent on the signal amplitude, there is a methodological question of whether 
it is expedient to normalize the EEG signals and how to do so. The absolute value of normalization that is sensitive to high-amplitude artifacts can be applied for normalization using the median of the absolute signal values; this was employed in our study. The median normalization of the absolute values of signal samples can also be considered a robust method. Furthermore, normalization of the absolute values of wavelet coefficients or histograms can also be used. To obtain optimum results, the discriminatory value for different parent wavelets should be compared. Higherfrequency resolution and information regarding the phase relationships of signals between channels represents an advantage of continuous wavelet coherence over mutual information in the wavelet scales. Thus, we did not realize calculations within conventional EEG frequency bands, as would be allowed by conventional wavelet coherence, but made this within wavelet scales. Smaller values were observed in $\mathrm{AD}$ patients compared to healthy controls in the left temporocentral and temporoparietal areas, as well as in the right temporocentral and temporooccipital areas.

Patients with AD exhibited a moderate disability, and this circumstance somewhat reduces the clinical use of these parameters. This parameter set could be of some diagnostic importance during the early stages of $\mathrm{AD}$ and in the case of a minimum cognitive deficit, if combined with biomarkers and MRI markers, which would require a further study related to MCI and mild $\mathrm{AD}$.

Thus, we have applied a new technique of mutual information between the absolute values of complex wavelet coefficients as a sensitive technique that may help to detect disorders in the neuroanatomical connectivity in patients suffering from AD. The ability of this technique to monitor nonlinear relationships between EEG channel records is probably the most important factor responsible for more statistically significant results in the detection of moderate AD compared to using wavelet coherence. The dependences on the frequency using this approach by wavelet scales and on the localization of evaluated electrode pairs suggest that there is a need to evaluate various frequency bands and various locations.

Acknowledgment. This study was supported by the research grant of the "Alzheimer's Foundation," Prague, Czech Republic.

The study was carried out in agreement with the contemporary internationally accepted ethical requirements related to research involving humans and approved by the
Ethical Committees of the Institutions where the authors work. Informed written consent was obtained from all subjects involved in the tests and attending physicians of patients suffering from Alzheimer's disease.

The authors, O. Vyšata, M. Vališ, A. Procházka, R. Rusina, and L. Pazdera, declare that the research and publication of the results were not associated with any conflicts regarding commercial or financial relations, relations with organizations and/or individuals who may have been related to the study, and interrelations of co-authors of the article.

\section{О. Витата ${ }^{1,2}$, М. Валіх ${ }^{2}$, А. Прохазка, Р. Русина ${ }^{3,4}$, Л. Паз- дера $a^{5}$}

\section{ЛІНІЙНА ТА НЕЛІНІЙНА СИНХРОНІЗАЦІЯ ЕЕГ У ПАЦІЄНТІВ ІЗ ХВОРОБОЮ АЛЬЦГЕЙМЕРА}

\author{
${ }^{1}$ Інститут хімічної технології, Прага (Чеська Республіка). \\ ${ }^{2}$ Карлов Університет, Градець Кральове (Чеська \\ Республіка).
}

3 Лікарня Томайєр та Інститут медичної післявузівської освіти, Прага (Чеська Республіка).

${ }^{4}$ Перший медичний факультет Карлова Університету в Празі та Головна університетська лікарня, Прага (Чеська Республіка).

${ }^{5}$ Група клінічного догляду Нейроцентру, Рихнов над Кнезноу (Чеська Республіка).

P е 3 ю м е

Як відомо, хвороба Альцгеймера (ХА) пов'язана з прогресуючим когнітивним дефіцитом у результаті істотної загибелі нейронів. Зменшення міжнейронних зв'язків може проявлятись як зміни ступеню синхронізації електричної активності взаємодіючих мозкових структур. Ми використовували методику оцінки вейвлет-когерентності для оцінки лінійної або нелінійної синхронізації зразків ЕЕГ, відведених від різних локусів кори. Визначення індексів взаємної інформації використовувалося для оцінки нелінійної синхронізації згідно 3 комплексними вейвлет-коефіцієнтами за вейвлет-шкалами. Було порівняно ступені синхронізації ЕЕГ-активності в групі пацієнтів, що страждали на ХА помірної тяжкості (оцінки за MMSE від 10 до 19 балів), та в групі із 110 контрольних здорових суб' єктів. Найістотніші зменшення індексів взаємної інформації у пацієнтів із ХА спостерігалися по третій шкалі для фронто-темпоральної зони; зменшення вейвлет-когерентності відзначались у тих самих зонах, що й зміни взаємної інформації. Саме ці зони зазнають переважної атрофії при ХА. Використаний новий метод базується на оцінках взаємної інформації за вейвлет-шкалами та демонструє більшу дискримінаційну здатність в умовах ХА, аніж визначення вейвлет-когерентності. 


\section{REFERENCES}

1. Z. Sankari, H. Adeli, and A. Adeli, "Wavelet coherence model for diagnosis of Alzheimer disease," Clin. EEG Neurosci., 43, No. 4, 268-227 (2012).

2. V. S. Afraimovich, N. N. Verichev, and M. I. Rabinovich, "Stochastic synchronization of oscillation in dissipative systems," Radiophys. Quantium Electron., 29, No. 9, 795-803 (1986).

3. M. G. Rosenblum, A. S. Pikovsky, and J. Kurths, "Phase synchronization of chaotic oscillators," Phys. Rev. Lett., 76, No. 3/4, 1804-1807 (1996).

4. J. Dauwels, F. Vialatte, and A. Cichocki, "Diagnosis of Alzheimer's disease from EEG signals: where are we standing?," Current Alzheimer Res., 7, No. 6, 487-505 (2010).

5. J. P. Lachaux, A. Lutz, D. Rudrauf, et al., "Estimating the time course of coherence between single-trial brain signals: an introduction to wavelet coherence," Clin. Neurophysiol., 32, No. 3, 157-174 (2002).

6. A. Klein, T. Sauer, A. Jedynak, and W. Skrandies, "Conventional and wavelet coherence applied to sensoryevoked electrical brain activity," IEEE Trans. Biomed. Eng., 53, No. 2, 266-272 (2006).

7. V. Sakkalis, T. Oikonomou, E. Pachou, et al., "Time-significant wavelet coherence for the evaluation of schizophrenic brain activity using a graph theory approach," 28th Annu. Int. Conf. IEEE, New York, EMBS'06 (2006).

8. S. Aviyente, "A measure of mutual information on the timefrequency plane," Proc. ICASSP, 2005, 481-484 (2005).

9. J. A. Gray, "Brain systems that mediate both emotion and cognition," Cogn. Emot., 4, No. 3, 269-288 (1990).

10. J. Jeong, J. C. Gore, and B. S. Peterson, "Mutual information analysis of the EEG in patients with Alzheimer's disease," Clin. Neurophysiol., 112, No. 5, 827-835 (2001).

11. T. Schreiber and A. Schmitz, "Surrogate time series," Physica $D$, 142, No. 3/4, 346-382 (2000).

12. C. W. J. Granger, "Investigating causal relations by econometric models and cross-spectral methods," Econometrica, 37, No. 3, 424-438 (1969).

13. J. Arnhold, K. Lehnertz, P. Grassberger, and C. E. Elger, "A robust method for detecting interdependences: application to intracranially recorded EEG," Physica D, 134, No. 1, 419430 (1999).

14. Y. He, Z. Chen, G. Gong, and A. Evans, "Neuronal networks in Alzheimer's disease," Neuroscientist, 15, No. 4, 333-350 (2009).

15. J. H. Morrison, S. Scherr, D. A. Lewis, et al., "The laminar and regional distribution of neocortical somatostatin and neuritic plaques: implications for Alzheimer's disease as a global neocortical disconnection syndrome," in: The Biological Substrates of Alzheimer's Disease, A. B. Scheibel and A. F. Wechsler (eds.), Acad. Press, Orlando (1986), pp. $115-131$.

16. C. J. Stam, B. F. Jones, G. Nolte, et al., "Small-world networks and functional connectivity in Alzheimer's disease," Cerebr. Cortex, 17, No. 1, 92-99 (2007).

17. C. Sorg, V. Riedl, M. Muhlau, et al., "Selective changes of resting-state networks in individuals at risk for Alzheimer's disease," Proc. Natl. Acad. Sci. USA, 104, No. 47, 1876018765 (2007).

18. Y. He, Z. Chen and A. Evans, "Structural insights into aberrant topological patterns of large-scale cortical networks in Alzheimer's disease," J. Neurosci., 18, No. 28, 4756-4766 (2008). 